\title{
The Development of 3DPageflip Service System to Improve Performance Customer Services in Bank
}

\author{
Roki Juniadi ${ }^{1)}$, Indri Astuti ${ }^{2)}$, Fadillah $^{3)}$ \\ ${ }^{1)}$ Universitas Tanjungpura, Pontianak, Indonesia \\ E-mail: rokijuna12@gmail.com \\ ${ }^{2)}$ Universitas Tanjungpura, Pontianak, Indonesia \\ E-mail: indribk91@gmail.com \\ ${ }^{3)}$ Universitas Tanjungpura, Pontianak, Indonesia \\ E-mail: fadilah.fkip@gmail.com
}

\begin{abstract}
This study aims to produce a 3Dpageflip service system design in the learning of customer service material, the final product of a 3Dpageflip service system to improve Customer Service performance, through learning activities using a 3Dpageflip service system is expected to help skilled Customer Service in serving customer satisfaction at the Bank. This research is a research on the development of a 3Dpageflip service system by using the Borg and Gall development stage, and the subject of the research is Customer Service. The design of the model is developed using the ADDIE model. From the results of the media expert validation and expert service model validation, and Customer Service questionnaires about the 3Dpageflip service design system, the 3Dpageflip service system is well used in learning customer service material at the Bank. The results showed that the average response value of 83.92 3Dpageflip service system meant that it was well received, tested and feasible to use in the material of the customer service system in improving Customer Service performance.
\end{abstract}

Keywords: Pengembangan, Pelayanan, 3Dpageflip

\section{INTRODUCTION}

Practicality and convenience are the main considerations in choosing something. With the development of mobile devices that allow everyone to do work, entertainment, and communication using just one device 3DpageFlip is an E-Book or digital book maker software, E-Catalog, E-Brochure with a back page of $3 \mathrm{D}$ effects and rotating effects within minutes. 3D PageFlip is the perfect Flipbook flash software for converting PDF, Word, PowerPoint files, to flipbooks into a realistic 3D digital magazine. With 3DpageFlip, you can make realistic and interactive 3D magazines, E-catalogs, E-brochures, E-Books by flipping through newspaper pages or anything else without knowledge or programming skills in Flash or HTML in no time. You can output 3D Digital Brochures online, offline (on your PC,
iPad, and others), even bur,n them to a CD or DVD or use them with a USB storage device.

Performance can also be described as the level of achievement of the implementation of activity in realizing the goals, objectives, mission, corporate vision contained in the formulation of a company's planning strategy. The assessment is inseparable from the process which is the process of processing inputs into outputs or assessments in the process of drafting policies, programs, activities that are considered important and influencing the achievement of goals and objectives.

Performance management is a process designed to improve the performance of organizations, groups, and individuals driven by managers. This process is based more on management by obstruction than management based on the command, although this also includes the need to emphasize high expectations of performance 
through such contracts. Targeting is a management process that ensures that every employee understands the rules and results that need to be achieved to maximize their contribution to the organization as a whole. In essence, goal setting allows employees to know what is required for them and the basis for what their performance and contribution are assessed.

The role of Customer Service is also one of the human resources needed by a company. In carrying out the service, the role of Customer Service is directly related to the choice of consumers, so a reliable Customer Service is needed. Customer Service plays a very important role as the spearhead in facing customers. In the business world, the task of a Customer Service is to provide services and foster relationships with the community. Customer Service is like the face of a company.

Services provided are services based on information and services that aim to provide customer satisfaction and can meet customer desires and needs. Banks as financial institutions engaged in the service sector must be able to provide the best service (service excellent) to be able to win the competition in an increasingly competitive situation. To deal with the increasingly tight banking competition, each Bank inevitably has to develop the concept of "the best service for its customers." This development aims to maintain existing customers and reach potential new customers. In addition to maintaining and increasing the number of customers, the Bank needs to maintain a good and positive image in the eyes of the community. To maintain this image the Bank can build it through an increase in the quantity and quality of the banking products produced, as well as through the quality of services provided to its customers. To support the achievement of these objectives, the banking institution must prepare employees who are competent, reliable, trustworthy, and able to handle various needs of its customers, especially in this case which is one of the spearheads of banking (regarding service) is Teller, Customer Service, and funding officer.

Quality of service to customers is a very important factor. In accordance with the results of the observation on February 9, 2018, conducted in the field there are several factors that directly influence the quality of services provided. First, good service is influenced by human factors (20\% employees) who provide services from 3 male Customer Service. Humans who serve customers must have the ability to serve customers quickly, precisely, and perfectly (30\%) from 3 Female Customer Service. In addition, employees must have the ability to communicate, be polite, friendly, and take full responsibility for customers and not yet $100 \%$ perfect of a total of 6 Customer Service in performing customer service. The second, good service must also be followed by the availability of facilities and infrastructure that support the speed, accuracy, and accuracy of the work. Infrastructure and facilities owned must be equipped with the latest technological advances. In the end, the infrastructure and facilities that are owned must also be operated by qualified human beings. So it can be said that both factors support each other. It means that these two factors must support each other to provide optimal service. Specifically to carry out all the supporting factors above, the most important thing to do is to improve the quality of the products offered, the right pricing strategy, promotion strategy, the quality of the workforce used, the availability of technology used, service to customers (customer satisfaction) , harmony between employees and leaders and employees with employees and other factors. It's just that each of the above factors cannot stand alone, but must be done in its entirety or together. That is, if one is not done, it will become lame and can thwart the success of achieving the company's goals.

The importance of service quality can be explained from two angles, namely from the point of view of operational management and marketing management, as seen from marketing management, service quality is one of the main elements in marketing (marketing mix), namely services, products, prices, promotions and distribution channels that can increase volume, sales and expand the company's market share. When viewed from the perspective of operational management, the quality of service is one of the important policies in improving the competitiveness of companies that must give satisfaction to consumers can exceed or at least equal the quality of service from competitors so that customer satisfaction can be fulfilled. Therefore "prioritizing customer satisfaction" is an awesome intention, how well a company is invited to do business usually depends on the people they employ.

Efforts to satisfy customer needs must be carried out profitably in a situation where both parties feel indeed, and no one has been harmed. Community demands for improving living standards, government regulations regarding customer rights, as well as increasingly complex business activities and the explosion of data and information, implies the necessity in improving the quality of services and improving the performance of service providers, namely the Bank Customer Service. The principle of excellent service in marketing activities can be made as a guideline for the Bank to carry out an excellent service activity that is intended to be set for the customers that they want to achieve. Through the principle of excellent service, this can lead to achieving the goals to be achieved by the Bank, especially in improving services to particular customers and all stakeholders in general. Excellent service is the maximum ability of a Bank Customer Service through a touch of humanity in serving or relationships with customers. The purpose of 
excellent service is; generate customer trust and satisfaction, retain customers to remain loyal to using the Bank's products or services. Customers of the Bank always want the services they receive in accordance with their expectations, even if there are customers who do not really care about the quality of service. For this type of customer who is less concerned about the quality of service, the employees still provide the same service standards, because in the end this type of customer also wants quality service. Therefore, good and quality service must be maintained and improved over time. It is due from time to time there will be changes in various fields that will eventually change customer behavior. These changes must be anticipated by trying to adapt to the existing services. The existing services must continue to be evaluated and improved according to the level of changes in customer behavior to achieve $100 \%$ satisfaction of the Bank's performance.

The gaps found in the service system still use module-based learning, or regular training carried out to provide operational service standards to Customer service and spend a lot of time and training costs. Performance is the work achieved by a Customer Service in carrying out their duties and responsibilities for that Customer Service must continue to improve service skills and human resources. Starting from the background above, the researcher is interested in researching the development of a $3 \mathrm{D}$ pageflip service system at the Bank's services.

\section{RESEARCH METHOD}

This study aims to develop a 3Dpageflip service system to improve the performance of Customer Service at the Bank. So the research used in this research is the method of development (Research and Development). This development takes the steps of Borg \& Gall's development research combined with the ADDIE design development model at the product development stage. This study includes the development of learning resource products in the form of developing a 3D pageflip service system to improve the performance of Customer Service at the Bank. The development of this service system is expected to be Customer Service to be able to learn easily and fun, and achieve the learning objectives by building the concept of service. As well as Customer Service can also learn independently and can adjust the capabilities of each itself.

\section{Research Location}

This research will be conducted at Bank Mandiri Tayan. This bank is a service excellence model for other banks. Therefore, the researchers considered that Bank Mandiri was very suitable to be used as the right research. For the time of the research, it can be adjusted according to the schedule provided.

Research Subject

The research subjects in this study were Customer Service at Bank Mandiri Pontianak as many as 6 Customer Service and Teller consisting of 3 men and three women. In addition, it is also supported by several informants, namely branch heads and customers.

Research Procedure

The procedure of research conducted by researchers in this development research was taken from the steps of Borg and Gall. The first step taken in this study is to analyze the Customer Service needs at the Bank related to the system used in the development of $3 \mathrm{D}$ pageflip services. Needs analysis is done by giving a questionnaire consisting of four questions to Customer Service. The data obtained from the results of the needs analysis is used as a guideline in the development of a service system, in this case, is a learning $3 \mathrm{D}$ learning mirror. The following data collection instruments can be seen in the table below:

1. Data collection

2. Product design

3. Validate experts

4. Validate the field

5. Final product

Model Development Steps

Borg \& Gall's research in the research model he developed established ten procedural steps, in this study the author only uses up to 9 models given the limitations of time and budget of the researchers' funds so that the application of research steps is adjusted to the research needs. It is in line with the opinion of Borg and Gall (in Sugiyono 2016: 37) which explains that it is possible to research on a small scale by limiting the number of stages of the entire steps.

Data collection technique:

1. Data Source
a. Customer service
b. Customer or customer
c. Document Data
d. Field Notes

2. Data Collection Techniques and Tools

Data collection techniques in this study use the following techniques:

a. Direct observation with the observation sheet tool.

b. Direct communication techniques with the interview sheet tool.

c. Documentary techniques with documentation tools.

d. Indirect communication with questionnaire.

Data analysis technique

Data analysis used in this study is quantitative and qualitative.

1. Qualitative Data 
Qualitative analysis is carried out to find out the results of the validation of the expert or validator on the 3D pageflip service system to improve Customer Service performance, how the Customer Service responds to the 3D pageflip service system and how to implement the 3D pageflip service system in the customer service system. The steps are as follows:

a. Analysis of the Validation Result of the 3DPlip service system

3Dpageflip service system validation will be carried out using two assessment fields, namely media (design) experts, service model experts (material).

1) Assessment of Media Experts (design)

2) Assessment of Expert Model Services (material)

3) Search for the average of each criterion with the 2006 Khabibah formula (in Irwan 2018: 75)

4) Looking for an average aspect with the 2006 Khabibah formula (in Irwan 2018: 75)

5) Finding the average total validation of each aspect of the media with the 2006 Khabibah formula (in Irwan 2018: 76)

6) Match the total average with the validity criteria of the modified media Khabibah 2006 (in Irwan 2018: 76)

b. Analysis of Customer Service Response Results

3. Quantitative Data

Quantitative analysis is carried out to determine the results of Customer Service learning using a 3D pageflip service system in improving Customer Service performance. The steps are as follows:

1) Gives a score on the results of Prestes and Postes of Customer

2) t-test of 2 Paired Samples

3) Comparing the significance value

4) Give conclusions

\section{A. Result}

\section{RESUlT AND DISCUSSION}

The following are the findings in the research activities for developing a 3D pageflip system to improve Customer Service performance.

1. Conceptual Model of 3D Flash Service System to Improve Customer Service Performance

The conceptual model of the service system is a preliminary study and the most important thing that must be done so that the service system will be designed according to expectations. The learning system design model used is ADDIE (A) analysis model, (D) design, (D) development, (I) implementation, and (E) valuation. Without design, the service system will not be resolved, because a job starts with the design stage. As for some of the operational standards features of good service in serving customers or customers, namely: a. Stage Using 3Dpageflip in the Customer Service service system

The findings indicate that the service system still uses CD recordings in understanding the customer service process. This service system essentially supports Customer Service to learn appropriately in serving customers, which in the digital era like today can all be used as digital, so that it is easier and more practical, because learning is the result of the interaction between stimulus and response. 3DpageFlip is a flipbook flash application that can be used to convert PDF, Word, PowerPoint, and Excel files to flipbooks. Flipbook flash software can create amazing magazines, catalogs, e-brochures, eBooks or e-newspapers in 3D. In other words, with this software, we can make the Customer Service system more attractive in accordance with operational service standards.

b. Planning Stage

Activities in the planning stage of making this service system define skills developed through devices that will be produced by formulating the objectives to be achieved; the service system is arranged in a systematic, directed, complete according to operational service standards.

In designing a 3D pageflip service system to improve Customer Service performance, researchers must have good planning so that the service system that will be produced is suitable for use by Customer Service. The planning carried out is Determining the purpose of the service system, Gathering service resources, Determining the content of the service system, Developing service training (rollpaly) to determine the level of mastery and success of the service system used in learning and skills training in customer service. With this planning, it will make it easier for researchers to conduct a 3D pageflip service system to improve Customer Service performance.

c. Service System Development Phase

This development stage is the form of the beginning of the 3Dpageflip service system to improve the Customer Service performance that will be generated. The success in service using the 3Dpageflip waiter system is highly dependent on the display design presented in the service system and includes service material. The 3D pageflip service system to be compiled must be interesting, the material in the $3 \mathrm{D}$ pageflip service system already includes from the entire material to be delivered, the material described in the 3D pageflip service system is in accordance with the objectives of customer service procedures. The initial design of the 3Dpageflip service system is digital cover page cover, introductory service video, table of 
contents and links, 3Dpageflip user stages, service photos, Customer Service service videos and service matrices, service evaluations, service cover videos, and library list.

The cover page includes, among others: link buttons, service system titles, illustration images (representing activities carried out in the discussion of the 3Dpageflip service system), and video service system authors. The table of contents is combined with a link because it contains information about the role of the 3Dpageflip service system page. The 3Dpageflip usage concept map shows the position between sub-material with one another.

Introduction that contains the use of 3Dpageflip competency standards, indicators that will be studied in the service system, manual usage of 3Dpageflip special key guide how to use, description description of the contents of the service system, prerequisite preliminary ability required to learn the service system, the ultimate goal to be achieved after Customer Service finished learning the 3Dpageflip waiter system, and the ability to check the list of questions even directly practiced in serving customers so that they can measure the initial Customer Service control over the competencies to be learned on a 3Dpageflip service system.

The part of learning or training activities consists of two activities, namely: activity one makes about the material of the service system which is able to explain the contents of the stages of serving customers who are seen and heard through 3Dpageflip video. Activity two made about the description of the material that is able to recover the content of the 3Dpageflip service system (stages, steps, and expressions in serving customers) which is heard through rollpaly practice (direct practice) Customer Service.

The final section makes about evaluations that must be done by Customer Service independently. The answer contains the questions in the evaluation that function so that the Customer Service can judge for themselves the results of what it has done because then the Customer Service can measure its abilities.

The success of the service system using 3Dpageflip to improve Customer Service performance, this depends on the display design that will be presented. Learning resources in the form of a 3D pageflip service system that is presented must be interesting, covering all material that is intended to be given, right on target learning objectives, providing insight to Customer service participants regarding the learning material of the customer service system. The conceptual model of writing and arranging a $3 \mathrm{D}$ pageflip service system is complete, the development phase of the service system is then the validation of the $3 \mathrm{D}$ pageflip service media design of experts.

a. Expert validation stage

After the 3Dpageflip service system has been completed, the next step will be realized by experts to find out the quality of the 3D graphics service system that is being developed before the service system is tested to Customer Service. In this study took two experts: media experts, the design of two people and two service model experts.

\section{1) Results of media expert assessment}

The assessment by design experts on the $3 \mathrm{D}$ pageflip service system was carried out by two experts. The aspects carried out in the design experts are the functional aspects of the service system simplicity, service system appearance aspects, service material reliability, aspects of display text, image appearance, color, layout, 3Dpageflip service, maintenance, 3Dpageflip service system security aspects.

Vamedia value indicates that the 3Dpageflip service system is said to be valid in terms of the 3Dpageflip service system function aspect, service system appearance, reliability, material text, color image, layout, use, maintenance and security of 3Dpageflip service system with 4.2 design values $4.2>3$ which means that the design of the 3Dpflflip service system has valid criteria.

2) Results of assessment of material experts on the service model

Assessment by material experts on the 3D pageflip service system model was carried out by two experts. The aspects carried out in the service material expert are aspects of the service system, service competence, material aspects, attitude in service, service evaluation.

Vamatter values indicate that the 3Dpageflip service system is said to be valid regarding aspects of material content and aspects of material presented with a value of 4.6 This material model value is $4.6>4.2$, which means that the $3 \mathrm{D}$ pageflip service system model has very good criteria.

b. Trial Stage

The next stage of the development of the $3 \mathrm{D}$ pageflip service system to improve the performance of Customer Service at the Bank is field trials. This trial was conducted to be easily understood by Customer Service. To fulfill the element of good or not a service system, several aspects are carried out, namely:

1) The language factor used must be in accordance with good and correct language rules. Besides that, the level of simplicity of the language used must be in accordance 
with the operational standards of Customer Service services at the Bank.

2) An attractive presentation style that attracts Customer Service to use a 3Dpageflip service system

3) Seeing the level of Customer Service ability so that the material presented is made so that Customer Service is easier to understand.

The trial of the 3D pageflip service system is carried out through 3 stages, namely, individual trials (3 Customer Service), small group trials (6 Customer Service), and large group trials (20 Customer Service), at Customer Service at Bank by providing questionnaires and observations at Bank Mandiri branch offices which will be used as input in revising the product. The implementation of the trial activities is as follows:

a) Observing the service system and responses from Customer Service during service to customers at the Bank.

b) Provide questionnaires (questionnaires) response to Customer Service after they are given 3Dpageflip service system material. Customer Service will later assess the language used, deficiencies and weaknesses of the assessment of each Customer Service as the subject of the trial.

1) Individual trial

The implementation of the first trial is an individual trial (one to one) in the implementation of this trial; it is expected that researchers can find out the response and comments of the subject of the trial about the design of the $3 \mathrm{D}$ pageflip system design that has been designed. In addition, from this trial, it is expected that researchers can see the deficiencies in the design of the 3Dpixflip service system as a reference in revising the 3Dpixflip service system design that is being developed.

The findings during the implementation of individual trials are as follows:

a) The trial was conducted on Tuesday 05 June 2018 at 16: 00-17: 00, at Bank Mandiri Tayan.

b) The test subjects consisted of 3 Customer Service with female gender. The selection of trial subjects was based on recommendations and the level of Customer Serviceability, namely one person with high-ability Customer Service, one person with moderate capability Customer Service, one lower-capable Customer Service.

c) The average value of the Customer service response is 4.46 with very good information. In addition to filling out the questionnaire, Customer Service also provides comments and suggestions on the shortcomings and lack of clarity of the content of the customer service system used, the results of these comments will later be a reference in revising the 3Dpageflip service system.

d) Through the results of the comments and suggestions given by Customer Service to the 3Dpageflip service system, the researcher does revisions in accordance with the previously suggested aspects. The revised results after the trial implementation are to add samples of customer service material.

2) Revision of the main product stage

After a small group trial, the researcher made improvements to the initial product produced based on the results of the initial trial. It is done to minimize shortages so that researchers will make design improvements. The results of this improvement are the main products of the developed device.

b. Main Field Testing Stage

1) Small Group Trials (Small Group Based Try Out)

The process at this stage carried out initial field trials on a scale at Bank Mandiri Tayan with 6 Customer Services selected based on recommendations and randomly generated with observation sheets and questionnaires to later analyze the results for input and discussion of the results to revise the product as a trial. The test is used to obtain information on whether the research uses a 3D pageflip service system to improve customer service performance better and more interesting in customer service learning.

The average total response value is 2.77 with enough information. In addition to filling out the response questionnaire regarding the 3Dpageflip service system, the researchers also asked Customer Service to provide comments and suggestions regarding the 3Dpageflip service system.

2) Operational Product Revision Phase

This staging process makes improvements to the products produced based on the results of the medium scale trial. It is done to minimize the lack of a 3Dpageflip service system so that researchers will make design improvements. This repair is the main product of the device being developed. The results of improvements based on the medium scale test are the procedures for welcoming customers, the clarity of the service stage.

d. Operational Filed Testing Stage

1) Large Group Trials (Field Try Out)

The process at this stage of the 3D pageflip service system product is tested again in a larger scale field. The large-scale trial conducted on the first two places was held on Thursday 21 June 2018 at 16: 30- 17:35 WIB on 
22nd June 2018 at Bank Mandiri Tayan at 10:00 p.m. to 11:00 p.m. with a total of 20 Customer Service members consisting of 11 male Customer Service and 9 female Customer Service as trial subjects equipped with questionnaire sheets to later analyze the results.

The implementation of large group trials is carried out by referring to improvements in the 3Dpflip service system that are revised according to suggestions and input from the individual and small group trial stages. Thus it is expected that in large group trials the 3D pageflip service system process can be done well. Based on the results of the Customer Service response that the average total response value is 3.64 with good information, or the $3 \mathrm{D}$ pageflip service system is feasible to use, this means the service system has experienced a huge improvement, especially in the existing aspects of video service enhancers, language improvement and clarity stage of customer service.

There is also a comparison of the results of revisions to individual scale, small scale and large scale tests which can be shown in Figure 1.

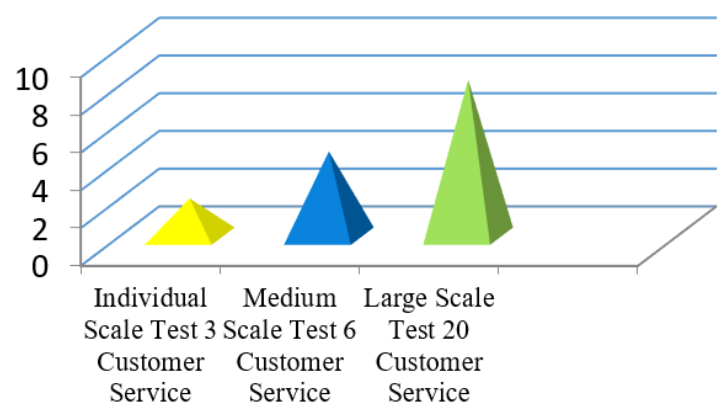

Fig. 1 Comparison of Trial Results of 3D Laser Service System

Based on graph 4.1 it can be seen that there has been an increase in the results of the medium scale trial of 2.77 and then revised, followed by a large-scale experiencing an increase of 4.36 very good categories, this means the 3D pageflip service system can be used in the Customer Service learning system process to improve performance.

e. Customer Service Response Results Against 3DPageflip Service System

In the development of a 3Dpageflip service system to improve Customer Service performance, researchers wanted to find out the response of 30 people on 3Dpageflip service system by Tuesday on August 07, 2018. By distributing questionnaires to get a score per item of the 3D pageflip system with the following details; Systematic item dimensions average score 4.32, composition score 4.32, material score 4.39, attitude score 4.51, and service evaluation score 4.54, the quality of service items provided by officers shows good results so it can be concluded that the Customer Service response to the 3Dpageflip service system with an average score is very good.

\section{f. Product Revision Final Stage}

Perform a final repair of the 3DPixip service system developed to produce the final product. At this stage, the analysis of the field trials was revised for the last time. Some improvements made to the $3 \mathrm{D}$ graphics service system include the appearance of the cover, the contents of the customer service system, and easy to understand.

2. Application of a 3Dpageflip Service System to Improve Customer Service Performance

The first step of the researcher as a facilitator is to prepare such as time and place, 3D pageflip learning materials, computers and books, and other stationery. It aims to make the process of implementing the 3Dpageflip learning system as planned. Furthermore, from a total of 20 Customer Service with details of 11 men and 9 Customer Servicewomen, they were directed to enter in the space provided then the researcher as the facilitator immediately greeted Customer Service and said greetings and shook hands to direct the existing seats so that they could interact for 3Dpageflip service system learning.

After everything is ready the researcher immediately introduces and explains the intent and purpose, Customer Service responds very well. To make it easier for Customer Service to learn about the service system, the researcher first gives an appreciation and direction about the material of the 3D service flip system; this gets a response from Customer Service. After finishing giving directions, the researchers immediately distributed 3Dpageflip service system material through computers and laptops.

The next step is that Customer Service starts to carry out learning activities starting from activity one. In the material of this one activity, the researcher explains what 3Dpageflip is and how to do the tutorial so that the instructions provided help Customer Service in understanding the service system created with the 3Dpageflip design.

The next step, the researcher immediately asked Customer Service to go to the second part, in this second activity the material studied was the procedure for serving customers in accordance with the standard operational services through 3Dpageflip video. The implementation of the two Customer Service activities looks serious, enthusiastic and conducive; there are only a few Customer Service inquiring about the procedures for 
material services which are activities one with two activities, getting the questions answered by the researcher and Customer Service understands that.

The researcher immediately reviewed the material that had been delivered and the understanding of Customer Service as preparation for direct practice (roolpaly) with 1015 minutes to find out how much Customer Service understanding of the service procedures made through 3Dpageflip while evaluating each service that was practiced right, after that the researcher reviewed the material practiced and asked other Customer Service to respond, the responding Customer Service was applauded. After running smoothly and the material can be understood, the researchers say thank you very much for the participation of Customer Service who have taken the time, by greeting the researchers to cover up learning by shaking hands with Customer Service.

The learning delivery scenario that is carried out in outline as follows:

1) Preliminary activities

2) Core activities

3) Closing activities

Based on the learning steps that have been taken, it can be seen that the learning process is only as a facilitator, while Customer Service learners who are more active, directed and enthusiastic in carrying out the learning process using a 3Dpageflip service system, thus a learning process will be more maximal.

3. Customer Satisfaction Against a 3Dpageflip Service System to Improve Customer Service Performance

The results of Customer Service service satisfaction in this study were to find out the success of the service process to customers' customer questionnaire form before using 3Dpageflip products and after using 3Dpageflip products. Customer Service is said to master the service system regarding customer satisfaction with the services provided with items of reliability (reliability), responsiveness (responsiveness), assurance (assurance), empathy (empathy), tangible forms, 3Dpageflip service system satisfaction scores can be seen in 4.3 notes as follows:

a. Before using the product (customer questionnaire pretest)

The initial stage of this implementation starts with giving a customer questionnaire in the form of an assessment score of 5 core points and around 21 questions asked. Prestes questionnaire aims to measure the initial ability of Customer Service in serving customers who come to the Bank. Prestes questionnaire is conducted on May 21, 2018.
The pretest results of customer questionnaires show that the average score on items is $(53.6,46,50.4,46.5$ 51.6) which means that Customer Service has not reached its maximum in service to customers because of the minimum completeness criteria of 80-100 service \%. In the implementation of the Customer Service service system, it has not been good in carrying out the stages to serve customers who come to the Bank. Score criteria: 20-40 = Low satisfaction, 41-79 = Medium satisfaction, $80-100=$ High satisfaction (Serves Quality).

b. After using the product (customer questionnaire posttest)

The posttest implementation of customer questionnaires was held on Friday 29 June 2018. The customer questionnaire posttest was conducted after Customer Service learned the 3Dpagefilp service system and applied it in daily work. The value of the posttest of the customer questionnaire obtained an average score on service items of, $(84.8,80.4,90.4,86.8$, 87.2), which obtained the value of customer service satisfaction criteria with a score of 80 $100 \%$. The average pretest score is $49.62 \%$ while the posttest mean score is $85.92 \%$. From these results, it can be concluded that there has been a significant increase in the results of Customer Service services between before the 3Dpageflip learning system and after learning the 3Dpageflip system to improve Customer Service performance.

c) T-test of Two Paired Samples

The two paired sample t-test is an analysis to test the differences in two paired samples, namely the pretest and posttest Customer Service results that have been obtained by the researcher from the customer questionnaire. The results obtained based on calculations made by each item, namely:

1) Item reliability (reliability)

Because the value of $\mathrm{t}$ arithmetic $>\mathrm{t}$ table (21.5> 1.812) then Ho is rejected, and $\mathrm{Ha}$ is accepted, meaning that there are differences in the results of customer service between before studying with the 3Dpageflip service system and after learning to use the 3D pageflip service system to improve Customer Service performance

2) Responsiveness items (responsiveness) Because the value of $\mathrm{t}$ arithmetic $>\mathrm{t}$ table (6.16> 1.812) then Ho is rejected, and $\mathrm{Ha}$ is accepted, meaning that there are differences in the results of customer service between before learning with a 3Dpageflip service system and after learning to use a 3D pageflip service system to improve performance 
3) Assurance items

Because the value of $\mathrm{t}$ arithmetic $>\mathrm{t}$ table $(15.20>1,812)$ then $\mathrm{Ho}$ is rejected, and $\mathrm{Ha}$ is accepted, meaning that there are differences in the results of customer service between before studying with the 3Dpageflip service system and after learning to use the 3D pageflip service system to improve Customer Service performance

4) Empathy items

Because the value of $t$ count $>t$ table (22.00> 1,812) then $\mathrm{Ho}$ is rejected, and $\mathrm{Ha}$ is accepted, meaning that there are differences between the results of customer service before learning with the 3Dpageflip service system and after learning to use a 3D pageflip service system to improve Customer Service performance

5) Tangible

Because the value of $\mathrm{t}$ arithmetic $>\mathrm{t}$ table (21.84> 1.812) then Ho is rejected, and $\mathrm{Ha}$ is accepted, meaning that there are differences in the results of customer service between before learning with a 3Dpageflip service system and after learning to use a 3D pageflip service system to improve Customer Service performance.

\section{B. Discussion}

1. Conceptual Model of 3D Flash Service System to Improve Customer Service Performance

Doing a design or design is the most important initial step that must be done in developing the service system. One of the learning system design models used in the 3D pageflip service system development activities, namely ADDIE Model, (Analysis, Design, Development, Implementation, Evaluation), requires a good and systematic stage that aims to maximize the expected process and results. Excellent service is a very good service or service that is in accordance with applicable service standards and owned by the agency that provides services. It can also be translated as a service that satisfies customers. Success in developing and implementing excellent service is inseparable from the ability to choose the concept of approach. The concept of excellent service is based on A6 Barata, (in Mhd Rusydi 2017: 73), which is to develop excellent service by harmonizing the concepts of attitude (Attitude), attention (Attention), action (Action), ability (Ability), appearance (Appearance), and Accountability.

The design of the 3Dpflflip service system development is a reconnaissance study conducted to obtain the information needed before carrying out development activities, or in other words, the design of the 3D pageflip service system development is a preliminary analysis carried out as a form of reference in planning service system writing activities. Thery (in Mhd Rusydi 2017: 60) classifies five elements of satisfying service, namely: equal and equal, given on time, fulfilling the required amount, continuous, and always improving the quality and service (progressive service). Everyone expects superior service, namely an attitude or way of employees in serving satisfactorily.

As explained in the findings of the research results, the results of the preliminary study on the development design began with the initial diagnosis of the service system, and the Customer Service learning resources used. It is intended so that later development activities carried out can improve performance in work and learning because the analysis is carried out on the competencies to be achieved. Will later all the competencies contained in the service operational standards can be provided by the service system material.

The preliminary study carried out later in the design of the 3D pageflip service system development is to analyze the characteristics of Customer Service. It is important because to overcome the problems that arise from the service system analysis is to produce a service system source that matches the characteristics of Customer Service.

The preliminary study carried out later in the design of the 3D pageflip service system development is to analyze the characteristics of Customer Service. It is important because it addresses the problems that arise from the results of the service system analysis. Service standard is a benchmark that is used as a guideline for the implementation of services and a reference for the assessment of service quality as a commitment or promise from the organizers to the community to provide quality services (Law on public service number 25 of 2009). In this service standard, there is also a service quality standard. Understanding the quality according to Goetsch and Davit 1994 (in Mhd Rusydi 2017: 58) is a dynamic condition that deals with products, services, people, processes and the environment that meet or exceed the expectations of those who want. Based on the findings of previous studies it can be concluded that Customer Service characteristics in understanding service material are still low so that the impact on employment in serving customers, most prominent is the difference in the style of each in implementing the service system. Through this information, the preparation of service system materials that will be carried out must use simple language, and in accordance with the style of Customer Service.

Through a series of activities that have been done before, the final activity carried out in the development design is to formulate the objectives of the service learning system to be achieved. The purpose of the formulation of the objective of the learning system that is carried out before making the service media is so that the researcher does not 
deviate from the original goal when the maker of the $3 \mathrm{D}$ pageflip service system.

The planning stage of the making and writing of the service system involves experts. Experts, in this case, are media or design experts, and service model experts at least those who influence the service system. It is through this planning stage that the 3Dpageflip server system can be compiled and developed in the next stage.

Difficulties during the implementation are designing the development of a 3D pageflip service system is the time and material constraints in conducting analyzes related to the information needed by researchers, the limited ability of observers when observing Customer Service characteristics, and the limited ability of observers to sort relevant material and systematic rearrangement of material in accordance with service standards.

3Dpageflip service system to improve Customer Service performance in this study is basically used as a substitute for training that does not yet exist in Customer Service, this 3D pageflip service system is made with language as easy as possible so that the 3Dpageflip service system can support Customer Service in developing service satisfaction concepts or be known with behavioristic theory because it emphasizes the formation of behaviors that appear to be learning outcomes.

Understanding in the service system learning that formed the visible behavior by the Customer Service itself. Therefore, understanding ability cannot be given by force, meaning concepts by service supervisors and when Customer Service forgets, the Customer Service cannot properly provide services to customers. 3Dpageflip service system design in this study provides a positive impact as evidenced by Customer Service activities in carrying out services can serve well regarding the stages of customer service.

2. Application of a 3Dpageflip Service System to Improve Customer Service Performance

The application of the service system is said to be important because the application of service system learning is a sequence of stories compiled by a researcher or training instructor so that a service system learning event occurs according to what is desired. Finished Customer Service or the student answers the greetings of the researcher, immediately introduces and explains the purpose and objectives of the learning system of 3DPlipflip service, Customer Service responds well.

To make it easier for Customer Service to learn about the material, the researcher first provides an apperception regarding the material of 3Dpageflip service system, and this gets a response from Customer Service. After finishing giving the apperception, the researcher directly distributes the 3Dpageflip service system to all Customer Service with each on his computer. The next step is the
Customer Service begins to carry out the learning activities of the service system material which starts with the activity or one. In the material of this one activity, Customer Service learned the 3Dpageflip tutorial when the learning process took place Customer Service seemed enthusiastic and conducive. After carrying out the learning system, the research service returned to reviewing the material that had been delivered and the understanding of Customer Service as preparation for conducting customer service practices. It aimed to find out how much Customer Service was understanding of customer service material. Based on the steps of the service learning system that has been carried out, it can be seen that in the learning system process, the service of the researcher is only as a facilitator, while the Customer Service is more actively directed and enthusiastic in carrying out the learning process using a 3Dpageflip service system.

Learning scenarios are arranged covering several stages of research including the preparation phase which includes preparation of teaching system services. Customer Service coding phase is done by preparing Customer Service before the service system starts. The third stage is the introduction, the thing that is done by the researcher to explain the important points of the 3D learning service learning simulation that will be conveyed. The individual work phase is where the Customer Service independently learns and tries to apply the distributed 3D service delivery system. The assessment stage is to assess the results of Customer Service service practices where researchers provide an assessment of the practice of Customer Service services. Next is the reflection and closing stage where the researcher tells the stages of the lack of service in Customer Service if there is still a mistake in working on the service system provided.

During the small group trial, the stages of the service system phases that have been compiled must be in accordance with the conditions of the material load submitted and the time allocation used or in other words the scenario of the service system must be in accordance with the real coding of the system during ongoing service. It is done so that when the 3Dpixflip service system is used with real conditions in the field, there is no obstacle to the suitability of the 3Dpageflip service system with the stages of the existing service system. This is in line with the opinion of Mulyatiningsih (in Irwan 2018: 128) the importance of conducting a small-scale trial in advance to anticipate errors that can occur during the actual implementation of the model, in addition to analyzing the obstacles that may be encountered and trying to reduce these constraints on when applying the next model. The results of small group trials show that the service system can be used as teaching material in learning using a Customer Serviceoriented approach. During learning activities, the use 
of a service system can help Customer Service in understanding the concept of a customer service system, only a few drawbacks of using a group 3D service system are the need to adjust learning time with the stages of learning activities in a 3D pageflip service system.

The response provided by Customer Service in the small group trial was $2.77 \%$ on average. It shows that the results of improvements to the simplicity of the material from the discussion carried out after the previous individual trials gave good results for the subjects of this small group trial. Or in other words, one of the important components of using a service system is to provide good learning motivation for Customer Service.

Whereas the response given by the large group trial subjects with an average value of $3.64 \%$ positive response or in other words during the implementation of learning using the 3Dpageflip service system Customer Service has a pretty good motivation in the development of its work. Customer Service System to Improve Customer Service Performance at Banks

Learning outcomes are a measure of the achievement of the learning objectives of the services performed. To find out how the results of Customer Service learning by using a 3Dpageflip service system researchers use a service system practice test that aims to determine cognitive learning outcomes, affective, physical customer service. The learning outcomes obtained show that the desired learning objectives of customer service experience achievement, namely Customer Service have improved both in terms of knowledge and attitudes and skills in service, this is in line with Sardiman's opinion (in Irwan 2018: 124) that the goal of learning is to gain knowledge marked with the ability to think, planting concepts and skills that are physical and spiritual and the formation of mental attitudes and behavior of students, will not be separated from the matter of planting values.

It is in line with service ethics starting from the behavior of Bank officers in various lines in meeting the needs and desires of customers by paying attention to which ones are good which are bad, which ones are right which are wrong. Vincent Gespersz (in Mhd Rusydi, 2017: 77) states that service quality includes the following dimensions:

a. Timeliness of service related to waiting and processing times

b. Service quality is related to accuracy or accuracy of service

c. Service quality is related to the politeness and friendliness of business people

d. Service quality is related to the responsibility in handling customer complaints

e. Service quality is related to the small number of service personnel and other supporting facilities f. Quality of service is related to location, service room, parking area, availability of information, and other guidance.

g. Service quality is related to environmental conditions, cleanliness, waiting rooms, air conditioning facilities, communication equipment, and music.

\section{CONCLUSIONS AND SUGGESTIONS}

\section{A. Conclusions}

Based on the results of research that has been carried out, in particular it can be concluded that the $3 \mathrm{D}$ pageflip service system to improve the performance of Customer Service in the Bank, with the conceptual model design of the 3D pageflip service system development, is a series of activities that are intact and become a reference in the process of developing a customer service system. With the stages from Brog and Gall and the ADDIE learning system design model and with several learning theories. The level of quality of service provided by Bank officers before and after using the 3Dpageflip service system is the maximum in serving, but some are not. However, if viewed from each dimension of quality to satisfaction perceived by customers, then: dimensions of item reliability (Reliability), Responsiveness (Responsiveness), Guarantee (Assurance), Empathy (Empathy), Physical (Tangible), quality of service items given by the officer shows better.

The application of the development of the 3D pageflip service system was carried out to improve the performance of the Customer Service at the Bank. The results of customer satisfaction with the Customer Service service using a 3D service flip service system can be seen from the results of the prestige and the posttest results. Results of customer prestige towards Customer Service services with items, reliability (Reliability) 53.6, responsiveness 46, assurance 50.4, Empathy 46, 5, and tangible 51.6. This achievement is done to measure the ability of the initial Customer Service stage before studying the material using a 3Dpageflip service system. While the results of the Customer Service posttest with items, reliability (Reliability) 84.8, responsiveness (responsiveness) 80.4, assurance (Assurance) 90.4, empathy (empathy) 86.4, and physical (Tangible) 87.2. This posttest was carried out aimed at measuring Customer Service capability after using a 3D pageflip service system to improve Customer Service performance.

Service system results through 3Dpageflip media to improve Customer Service performance can also be seen from the paired sample $\mathrm{T} 2$ test results, the sample referred to here is the results of the customer's prestige and posttest that have been obtained through each of the Customer Service service items that are carried out namely: Item 
reliability (reliability) because the value of $t$ count $>t$ table $(21.5>1.812)$ then $\mathrm{Ho}$ is rejected, and $\mathrm{Ha}$ is accepted, meaning that there are differences in the results of customer service between before learning with a 3Dpageflip service system and after learning to use a 3D pageflip service system to improve Customer Service performance. Responsiveness items (responsiveness) because the value of $t$ arithmetic $>t$ table $(6.16>1.812)$ then Ho is rejected, and $\mathrm{Ha}$ is accepted, meaning that there are differences in the results of customer service between before learning with a 3Dpageflip service system and after learning to use a 3D pageflip service system to improve performance. Assurance item (assurance) because the value of $t$ count $>t$ table $(15.20>1,812)$ then $\mathrm{Ho}$ is rejected, and $\mathrm{Ha}$ is accepted, meaning that there are differences in the results of customer service between before learning with a 3Dpageflip service system and after learning to use a 3D pageflip service system to improve Customer Service performance. Empathy (empathy) item because the value of $t$ count $>t$ table $(22.00>1,812)$ then Ho is rejected, and $\mathrm{Ha}$ is accepted, meaning that there are differences in the results of customer service between before learning with the 3Dpageflip service system and after learning to use a 3D pageflip service system to improve Customer performance Service. Tangible because the value of $\mathrm{t}$ arithmetic $>\mathrm{t}$ table (21.84> 1.812) then $\mathrm{Ho}$ is rejected, and $\mathrm{Ha}$ is accepted, meaning that there are differences in the results of customer service between before learning with a 3Dpageflip service system and after learning to use a 3D pageflip service system to improve Customer performance Service.

\section{B. Suggestions}

Based on the results of research and development the following are some suggestions that the researchers convey. It is necessary to be careful in designing a 3D pageflip service system in this learning, one when analyzing the characteristics of Customer Service. It is done so that when the 3Dpageflip material is compiled, the language and the level of difficulty produced are in accordance with the characteristics of the Customer Service. Perseverance in collecting and compiling material that will be used to write this 3Dpageflip material, the preparation of the material must refer to the characteristics of Customer Service so that it can easily help Customer Service when the learning process. Color selection in concept emphasis, font selection in writing in 3Dpipflip design, should be adjusted to the characteristics that will be conveyed so that it can be easily understood by Customer Service as a user of the 3Dpageflip service system. This 3Dpageflip service system can be further developed in the process of learning service materials involving Customer Service. In addition, it is necessary to develop research similar to different subject matter, so that there is hope that there will be new products of a similar type and even better so that they can provide innovation or renewal in the world of customer service skills on an ongoing basis.

\section{REFERENCES}

Brog, Walter R.,\& Gall, Meredith D. 1983. Educational Research (An Introduction) New York: Longman, Inc.

Irwan. 2018. Pengembangan Media Booklet dalam Pembelajaran Ikatan Kimia pada mata Pelajaran Kimia Sekolah Menengah Atas. Pontianak: FKIP Universitas Tanjungpura.

Khabibah, Siti. 2006. Pengembangan Model Pembelajaran Matematika Dengan Soal Terbuka Untuk Meningkatkan Kreativitas Siswa Sekolah Dasar. Surabaya: UNS.

Republik Indonesia. Undang-Undang Republik Indonesia Nomor 25 Tahun 2009 tentang Pelayanan Publik.

Rusydi, M. 2017. Customer Excellence. Yogyakarta: Gosyen Publishing.

Sugiyono. 2016. Metode Penelitian \& Pengembangan Reasearch and Development. Untuk Bidang Pendidikan, Manajemen, Sosial,Teknik. Bandung: Alfabeta. 